DOI: $10.15290 /$ bsl.2018.13.15

\title{
Dariusz Piechota
}

Wydział Humanistyczny

Uniwersytet Marii Curie-Skłodowskiej w Lublinie

e-mail: darekpiechota@o2.pl

ORCID: 0000-0002-7943-384X

\section{Narkotyczna odyseja z rozkładem społecznym w tle - Ślepnac od świateł Jakuba Żulczyka}

Ślepnac od świateł to ponowoczesna powieść środowiskowa, ukazująca egzystencję mieszkańców wielkiej metropolii, uwikłanych w nieustanną konsumpcję, która stanowi antidotum wobec permanentnej samotności oraz pustki duchowej. Żulczyk jest pisarzem niezwykle wrażliwym na problemy teraźniejszości, eksplorującym nowe obszary społeczne, potrafiącym - wskutek wykorzystania elementów poetyki naturalizmu - wyeksponować konflikty zachodzące między jednostkami, a także ukazać, w jaki sposób determinizm środowiskowy oraz biologiczny wpływa na ich losy. Świat przedstawiony $\mathrm{w}$ powieści okazuje się niezwykle okrutny i bezwzględny, gdyż nie ma w nim miejsca na jakiekolwiek sentymenty. Ślepnąc od świateł, jako utwór obrazujący społeczeństwo, które zachwycone kulturą konsumpcyjną marnuje swoje możliwości rozwoju, przypomina dziewiętnastowieczną powieść „o społecznym rozkładzie”. W niniejszym szkicu interesować mnie będą dwie płaszczyzny utworu, na których dokonuje się owa destrukcja oraz pojawiające się niepokoje społeczne na początku XXI wieku.

Przestrzeń w Ślepnąc od świateł wykreowana została z punktu widzenia głównego bohatera, będącego jednocześnie narratorem opowieści. Żulczyk powraca do modernistycznego toposu miasta potwora, polipa, rozrastającego się i "pożerającego" swoich mieszkańców ${ }^{1}$. Cała metropolia staje się

\footnotetext{
1 Por. W. Gutowski, Symbolika urbanistyczna w literaturze Młodej Polski, w: Miasto - Kultura Literatura. Wiek XIX, red. J. Data, Gdańsk 1993.
} 
przestrzenią profanum, zaś sacrum znajduje się poza jej granicami, najczęściej w wyimaginowanych, egzotycznych krajach. Jacek, główny bohater powieści, pragnie wyjechać do Argentyny, ponieważ znajduje się ona daleko od Polski. Sacrum w powieści kojarzy się z utopią eskapistyczną, przestrzenią, w której człowiek odzyskuje wewnętrzną harmonię. Protagonista podświadomie pragnie uwolnić się od Innych, odrzucając świat ludzi oraz instytucji, którym podlega, ucieka $\mathrm{w}$ samotność.

Przechodząc do sposobu narracji, warto podkreślić, iż dominują tu wypowiedzi pierwszoosobowe, na skutek czego owe partie charakteryzuje subiektywizm. Przestrzeń Warszawy poznajemy fragmentarycznie i ogranicza się ona głównie do dzielnic, w których Jacek spotyka się ze swoimi klientami: Mokotowa i Saskiej Kępy. Wielokrotnie wzmiankowane są także ulice (Świętokrzyska, Nowy Świat, plac Zbawiciela), na których znajdują się modne lokale, gdzie często przebywają krezusi, bananowa młodzież².

Jednym z najpopularniejszych miejsc jest klub w centrum Warszawy o nazwie nieco przewrotnej "Betlejem”, w którym spotykają się przedstawiciele różnych grup społecznych. To demoralizujące siedlisko zła, którego właścicielem okazuje się kryminalista zajmujący się nielegalnym handlem wszelkiego rodzaju używkami. Pisarz dokonuje demistyfikacji społecznych stereotypów na temat przedstawicieli świata przestępczego, przebywających głównie w popularnych, drogich lokalach, unikając spelun oraz restauracji typu fast food, które z kolei stają się bezpieczną przestrzenią do rozmów $\mathrm{z}$ osobami spoza kręgu. Warto wspomnieć, iż w barze z chińskim jedzeniem Jacek spotyka się z zaprzyjaźnionym policjantem w celu zdobycia poufnych informacji ${ }^{3}$. Dawne miejsca kryminogenne, takie jak karczmy czy szynki, zostały wyparte przez luksusowe restauracje i hotele, na co niewątpliwie wpłynął status materialny przedstawicieli półświatka ${ }^{4}$. Na marginesie mówiąc, w XIX wieku przestrzenią kryminogenną było Powiśle ${ }^{5}$, gdzie mieszkańcy w ekstremalnych warunkach walczyli o przetrwanie. Dzielnica przypominała getto, w którym współegzystowali przestępcy, ludzie zdegradowani moralnie oraz osoby żyjące na skraju ubóstwa. Na przestrzeni dziejów osoby zajmujące się nielegalnymi interesami przeniknęły do innych dzielnic Warszawy, zaś

\footnotetext{
2 Bananowa młodzież to dzieci bogatych rodziców, które mogą sobie pozwolić na nieustanne zaspokajanie konsumpcyjnych potrzeb, używając niekiedy nielimitowanych kart kredytowych swoich rodziców. Więcej na ich temat piszę w szkicu Śladami ponowoczesnego filistra, "Świat Tekstów. Rocznik Słupski" 2016, nr 14, s. 60-61.

3 J. Żulczyk, Ślepnąc od świateł, Warszawa 2014, s. 171. Wszystkie cytaty pochodzą z tego wydania i oznaczone są numerem strony.

4 Por. E. Ihnatowicz, Miasto kryminalne?, w: Miasto - Kultura - Literatura. Wiek XIX, s. 114-115.

5 Por. tamże, s. 116.
} 
handel narkotykami stał się zajęciem zapewniającym ogromne profity. Wielu dilerów inwestuje zarobione pieniądze w nieruchomości. Przykładem może być chociażby dom weselny "Jezioro Łabędzie", należący do szefa mafii, a stanowiący wyłącznie przykrywkę do prowadzenia nielegalnych interesów.

Akcja powieści Żulczyka rozgrywa się głównie nocą. Warszawę poznajemy z perspektywy wertykalnej, jak i horyzontalnej. Charakterystyka miasta zmienia się wraz z nastrojem bohatera. Na początku powieści dominuje impresjonistyczny opis:

Miasto wygląda jak nabazgrane kolorowymi flamastrami na czarnej płachcie przez ogromne, nadpobudliwe dziecko. Gdzieś z oddali przebija się uszkodzona, świąteczna melodia, przez szum, przez zupę z głosów i kroków, pracujących silników, trzask zamykanych drzwi. Ta melodia dźwięczy mi w całym ciele jak zapowiedź bólu zęba [s. 9].

Migawkowa charakterystyka miasta przypomina kadr filmowy, w którym zacierają się kontury między przedmiotami. Narrator zwraca uwagę na ulotność kolorów i dźwięków, tworzących kakofoniczną mieszaninę. Wrażenie chaosu potęguje również tłum ludzi pojawiający się na ulicach:

Wylewają się na zewnątrz, w światła i ciemność, w swoje życie, w weekend, $\mathrm{w}$ hałas, jak rozsypane ogromną dłonią paciorki. [...] Miasto ma swoje cykle dobowe. W konkretnych częściach miasta imprezy zaczynają się, szczytują i kończą o konkretnych godzinach [s. 12].

Gwar ulic, tłum śpieszących się ludzi potęgują uczucie osaczenia jednostki, dla której życie w stolicy staje się udręką. Metropolia w Ślepnąc od świateł przypomina żywy organizm, na skutek personifikacji: „Miasto otwiera oczy, zamknięte w dzień, budzi się cicho i ciężko, przypomina schlanego mężczyznę" [s. 9]. Warszawa "otwiera usta" i "chce jeść” [s. 10]. W jej opisie Żulczyk posługuje się poetyką naturalistyczną:

Miasto oddycha, ciężko sapie, próbuje odkrztusić nagromadzoną $\mathrm{w}$ gardle flegmę, a jego oddech idzie prosto z flaków, z kanałów, nieświeży i ciężki; jego serce łomocze jak wielki bęben. Czuję, jak po mieście rozsypują się rozszerzone źrenice, uśmiechy, okrzyki jak brzęczące pięciogroszówki [s. 12].

Deprecjacja przestrzeni miejskiej przejawia się w pejoratywnych określeniach. W porównaniu stolicy do ludzkiego organizmu, Żulczyk eksponuje jej chorobliwy stan. Przymiotniki opisujące postępujący proces agonii potęgują w czytelniku uczucie wstrętu i obrzydzenia. Metropolia jest wiecznie nienasycona, ciągle potrzebuje nowych ludzkich ofiar. 
Na początku powieści narrator zachowuje dystans do opisywanego miasta, co wynika z możliwości jego kontrolowania. Wraz z pojawiającymi się problemami w życiu Jacka, Warszawa przeobraża się w rozrastający nowotwór, osaczający bohatera:

Miasto jest chore. Czuję to, chce mu się wymiotować, pod chodnikami pulsuje zła, żołądkowa treść, która tylko czeka, aby wyciec, wydostać się z otworów kanalizacyjnych, wypełznąć ze szczelin w kostce brukowej, wylać się, pokryć wszystko tłustą na dwa palce warstwą [s. 250].

Można powiedzieć, że Jacek zostaje zainfekowany przez chore miasto:

To miasto jest jak tropik, procesy gnilne zachodzą tu o wiele szybciej niż poza jego granicami. Wstrzykuje toksyny do krwi, do brzucha, pod skórę. Czuję się jak na początku śmiertelnej choroby. Muszę zmienić planszę. Oczyścić organizm. Inaczej rozpuszczę się $\mathrm{w}$ pianę.

Warszawa mnie zabija, ale ten proces boli nas oboje. Zabójca cierpi bólem wszystkich swoich ofiar, ale $\mathrm{w}$ przeciwieństwie do nich nie może umrzeć. Warszawa. Ogromna, rozkładająca się za życia masa. Słyszę, jak skomle, cicho, z daleka, jak zamknięty w bagażniku pies [s. 272].

Pojawiające się w cytacie brud i postępująca destrukcja są czytelnymi atrybutami modernistycznego miasta chaosu ${ }^{6}$, paraliżującego ludzkie działania, systematycznie niszczącego wewnętrzną harmonię jednostki. Ogromna gnilna masa pochłaniająca coraz większe terytorium stolicy oraz kolejnych jej mieszkańców nasuwa skojarzenia z poetyką dekadencką. Poczucie wewnętrznej pustki potęguje otchłań przestrzeni:

To betonowy ekosystem, którego jestem częścią, nawet gdybym obserwował go z atmosfery. Czterdzieści trzy piętra pode mną jest asfalt, zmrożony, posypany piachem, udekorowany śmieciami, rzygowinami, krwią, pod asfaltem jest czarna, pulsująca maź i ja jestem przytwierdzony na stałe do tego piachu, asfaltu, do tej mazi, przytwierdzony niewidzialną linią, wszczepioną w mój kark. Okolice wszczepienia są zakażone. Pieką jak grzybica [s. 239].

Warszawa w perspektywie wertykalnej, dzięki zastosowaniu hiperbolizacji, przypomina cmentarzysko. Negatywna deskrypcja owego miejsca sugeruje katastrofę, która dokonała się zarówno w porządku egzystencjalnym jak i kosmicznym ${ }^{7}$. Miasto $\mathrm{w}$ powieści Żulczyka przeobraża się w martwą przestrzeń:

6 Por. W. Gutowski, Symbolika urbanistyczna w literaturze Młodej Polski, s. 201.

7 Por. tamże, s. 196. 
Warszawa jest pustynią. Składa się z krwi i cementu. Jej mieszkańcy są mieszkańcami pustyni. Mogą umrzeć każdego dnia. Grzebią paznokciami w krwi i cemencie, aby znaleźć wodę. Jestem mieszkańcem pustyni. Właśnie zostawiam ją za sobą. Nie szkoda mi jej. Nie szkoda mi niczego. [...] Na moich oczach miasto nagle zamienia się $\mathrm{w}$ sen [s. 510].

Pojawiająca się pustynia okazuje się synonimem entropii oraz pustki ${ }^{8}$, przestrzenią stłumienia i zaniku życia. Warszawa to ziemia jałowa, po której błąkają się mieszkańcy ${ }^{9}$. Miejskiej demoralizacji szczególnie podatni są ludzie wrażliwi i empatyczni ${ }^{10}$, którzy na skutek utraty ideałów popadają w stan wewnętrznej pustki, paraliżującej ich przed podjęciem jakiegokolwiek działania.

\section{Panorama społeczeństwa polskiego z kokainą $\mathrm{w}$ tle}

Ślepnąc od świateł to przede wszystkim powieść o ludziach zafascynowanych kulturą instant, w której „wszystko jest ujednolicone i nastawione na łatwą przyjemność"11. Postępująca makdonaldyzacja społeczeństwa przyczyniła się do rutynizacji ludzkich zachowań skoncentrowanych na triadzie: nowe doświadczenie - przyjemność - szybkość ${ }^{12}$. Nieograniczony dostęp do najnowszych trendów wpłynął na powstanie nowoczesnych wzorców normatywnych obowiązujących w społeczeństwie konsumpcyjnym, gloryfikujących hedonistyczny, beztroski styl życia. Wzorce te okazują się niezwykle złudne, gdyż wywołują lęki, fobie oraz niepokoje wynikające z ich iluzoryczności urzeczywistnienia.

Bacznym obserwatorem oraz komentatorem warszawskiego społeczeństwa jest operujący ironią narrator, wypowiadający się krytycznie na temat moralności mieszkańców ponowoczesności. Już na początku powieści dowiadujemy się o ich typowym stylu życia:

Miasto jest już nasycone ludźmi. Idą w grupach, wyszczerzeni do najbliższych paru godzin życia, wylewają się z przejść podziemnych, wsiadają do i wysiadają z taksówek. Jeszcze wyprostowani, jakby przyczepieni do niewi-

8 Por. tamże, s. 190.

9 Por. E. Paczoska, Lalka, czyli rozpad świata, Warszawa 2008, s. 240.

10 Por. J. Bachórz, Miasto z perspektywy Kraszewskiego, w: Miasto - Kultura - Literatura. Wiek XIX, s. 69.

11 Por. A. Trześniewska, Człowiek w sieci „kultury instant”. O powieści Dawida Kaina "Za pięć rewolta”, „LiteRacje” 2013, nr 2, s. 60.

12 Tamże. 
dzialnych strun. Jeszcze młodzi w ten najbardziej irytujący sposób: sprawiający wrażenie, jakby przebrali się w ubrania własnych rodziców. Maszerujący. Wyprostowani. Wzorowi oficerowie własnych życiorysów. Idący po drobne zwycięstwa, po identyczne, nudne przegrane. Biegnący przed siebie po to, aby na chwileczkę zapomnieć. Przyszli lub obecni menedżerowie średniego szczebla, asystenci i asystentki, czyjeś prawe lub lewe ręce, studenci albo ich sprytniejsi koledzy. [...] Część z nich już mnie potrzebuje. Niektórzy niedługo zaczną.

Niektórzy może chcieliby, aby gdzieś na wiszącym nad tym wszystkim powietrzu, tym powietrzu, które ma znamiennie czarny kolor, było coś jeszcze. Jakiś głos. Jakieś echo. Jakaś prawda. Jakiś skarb. Niektórzy może łudzą się, że to coś tam jest, ale większość z nich w ogóle o tym nie myśli. Myślą o jedzeniu, seksie, płatnościach, podatkach. Przede wszystkim myślą o pieniądzach. O tym, że mają ich za mało. Ci, którzy myślą o czymś więcej, są z góry na przegranej pozycji. Są zdekoncentrowani. Z rozkojarzonym błędnikiem, jakby coś nagle uderzyło ich w skroń [s. 21-22].

Priorytetowym celem mieszkańców stolicy okazuje się kariera oraz pomnażanie majątku, dlatego też bardzo chętnie biorą udział w przysłowiowym wyścigu szczurów, wyzbywając się wszelkich zasad moralnych. Żulczyk podkreśla, iż kluczową rolę odgrywa także nieskazitelny wygląd, budujący prestiż danej osoby w przestrzeni publicznej. Osoby rozmyślające nad sensem egzystencji skazane są na porażkę, gdyż refleksje natury filozoficznej dekoncentrują ich w pomnażaniu majątku.

Warszawiacy skupiają się wyłącznie na trzech czynnościach. Po pierwsze, nieustannie „mówią bezwładnie” [s. 36], ich długie monologi dotyczą spraw przyziemnych, a tematyka rozmów ogranicza się do zarobków, romansów, plotek. Po drugie, ciągle „handlują swoimi pomysłami, wymyślają kampanie marketingowe" [s. 36]. Nie bez powodu większość karierowiczów uzależniona jest od narkotyków. Kokainę zażywają politycy, lekarze, menedżerowie, pracownicy telewizji, pisarze, malarze, muzycy, adwokaci itd. Paradoksalnie klienci Jacka wierzą, iż narkotyki zapewnią im uczucie wolności. Bohater sarkastycznie stwierdza: „handluję złudzeniem, że rzeczywiście może im się to udać w życiu” [s. 66]. Jacek niczym psychoanalityk i socjolog potrafi wskazać źródła oraz przyczyny, dlaczego tak wiele osób sięga po substancje odurzające:

Ludzie siedzą w domach. Umierają w nich. Oglądają telewizję. Piją wódkę. Przystawiają żonom żelazka do twarzy. Biją dzieci. Potem te dzieci płaczą same na klatkach schodowych. Niedługo potem zaczynają brać sterydy. Albo palić brauna, aby zasnąć. Bo wszyscy tutaj, i dzieci, i ich rodzice, śpią ciężko i tyle [s. 105]. 
Źródłem pogrążania się w nałogu jest monotonna egzystencja, poczucie obojętności oraz pustki. Mieszkańcy miasta odczuwają przesyt, zmęczenie cywilizacyjne i egzystencjalne ${ }^{13}$, potęgowane nieustannym udziałem $\mathrm{w}$ wyścigu szczurów. Jednym ze sposobów nadania życiu sensu oraz ukojenia skołatanego umysłu staje się zażywanie narkotyków. Świadomy tego Jacek doskonale zdaje sobie sprawę z faktu, że każdy klient ,,jest twoim dożywotnim klientem i zrobi wszystko, aby dostać to, co mu sprzedajesz" [s. 179]. Z czasem nałóg przejmuje władzę nad człowiekiem, który traci kontrolę nad życiem:

Kokaina jest wszystkim. Jest krwią, która płynie przez życie, przez interesy, przez pieniądze. To nie kokaina zabiła tę dziewczynę, którą potrącił mój były najlepszy klient, to nie kokaina zabiła kiślowatego. Zabiło ich rozkojarzenie. Zdezorientowanie. Nieumiejętność wyhamowania [s. 199].

Żulczyk okazuje się bacznym analitykiem społeczeństwa polskiego, które przypomina społeczeństwo narcystyczne ${ }^{14}$. Współczesny świat, jak pisze Christopher Lasch, odrzuca refleksję na temat przyszłości, koncentrując się na teraźniejszości ${ }^{15}$. Mimo uwolnienia od ciężaru przeszłości, jednostka egzystująca w epoce ponowoczesnej odczuwa niepokój potęgowany niezaspokojonym pożądaniem ${ }^{16}$. Najwłaściwszą postawą społeczną zdaje się tzw. życie chwilą, odrzucenie balastu przeszłości, wskutek czego człowiek traci poczucie historycznej jedności ${ }^{17}$. Bohaterowie Ślepnąc od świateł traktują swoją egzystencję w kategoriach performansu, nie potrafią żyć bez publiczności, której modelową czynnością jest ich podziwianie. Warto podkreślić, iż w XIX wieku publiczne wystąpienia odzwierciedlać miały wewnętrzne życie aktora. Ten romantyczny kult szczerości i autentyczności, jak pisze Lasch, został obecnie zniszczony przez maski, które raz założone zatarly granice między życiem publicznym a prywatnym ${ }^{18}$, w konsekwencji czego ludzie zaczęli postrzegać własną pozycję społeczną jako odbicie wypracowanych przez nich umiejętności i zdolności. Rosnące rozczarowanie przyczyniło się

13 Por. M. Dąbrowski, Literatura jako nośnik etycznego dyskursu epoki. Fin de siècle i fin de millénaire, w: Etyka i literatura. Pisarze polscy lat 1863-1918 w poszukiwaniu wzorców życia i sztuki, red. E. Ihnatowicz i E. Paczoska, Warszawa 2006, s. 394.

14 Por. Ch. Lasch, The Culture of Narcissism. American Life in an Age of Diminishing Expectations, London- New York 1991.

15 Tamże, s. XVI.

16 Tamże.

17 Tamże, s. 15.

18 Tamże, s. 28. 
do zaniedbania własnego ego przez jednostki narcystyczne, popadające $\mathrm{w}$ delirium pożądania ${ }^{19}$. Najważniejszą wartością w życiu stały pieniądze:

Dla większości te pieniądze są po to, by błyszczeć. By się obwieszać. By celebrować. Przykryć złotem, materiałami czasy, gdy czuli się jak śmieci wystawione na klatkę, jak zepsute jedzenie. Są po to, by je spalić. By okazać im pogardę. Oni zarabiają pieniądze po to, by zemścić się na nich za nieobecność. Nie ma nic bardziej kolorowego i żałosnego jednocześnie niż barbarzyńca po awansie [s. 246-247].

Nader interesująca w powieści jest kreacja głównego bohatera, przypominającego człowieka bez tożsamości. Mężczyzna prowadzi zdrowy tryb życia (nie pije alkoholu, nie zażywa narkotyków), przestrzega swoistego kodeksu zawodowego (dystans wobec klientów). Ma ściśle określony grafik pracy. Niedziela nie jest dla Jacka dniem wolnym, gdyż tego dnia jego klientami są osoby zarabiające "naprawdę grube pieniądze; są szefami grup inwestycyjnych, lobbystami, synami i zięciami, ludzi z setki «Wprost», restauratorami, developerami" [s. 159]. Jacek wydaje się być pozbawiony empatii, a jedynym jego celem jest zarabianie pieniędzy. Mężczyzna postrzega siebie jako człowieka sukcesu, który zrobił karierę finansową, wyrzekając się przyjemności. Ten zdobywca świata krytycznie wypowiada się na temat pracujących trzydziestolatków:

Kredyty. Wyrzeczenia. Próby zachowania jakiejkolwiek autonomii. Związki, które prędzej czy później trafi szlag. Ukrywanie się. Ucieczki. Dwa, trzy, cztery, pięć, osiem tysięcy złotych miesięcznie. Mniej lub bardziej niewolnicze stawki. Podatki. Prywatne ubezpieczenia medyczne lub ich brak. Za dwadzieścia lat każdy z nich albo będzie żulem, albo takim jak wszyscy inni prolem, kmiotem klasy średniej z wiecznie niespłaconym debetem na koncie. [...] Widziałem ludzi w moim wieku skażonych przez swoich rodziców, napchanych przez fałszywe obietnice, nakarmionych kłamstwem - że życie jest jakąś szansą, że gdzieś tam czeka na nich szczęście i spełnienie, że świat, w którym funkcjonują, pozwoli im stać się wymarzonymi wersjami siebie [s. 103].

Życie współczesnych trzydziestolatków okazuje się ponure, gdyż ich egzystencja skupia się wyłącznie na morderczej pracy. Niepokój dotyczący niestabilnej sytuacji finansowej sprawia, iż nie tylko tracą radość życia, ale również szybko się starzeją. Świat, w którym egzystują jest fundamentalnie zepsuty, gdyż jedyną szansą na szybkie wzbogacenie się są nielegalne interesy. Jacek jako wyrachowany diler dawno stracił złudzenia co do tego,

19 Tamże. 
że można zrobić szybką karierę, przestrzegając zasad moralnych i etycznych. Interesujący okazuje się sposób, w jaki mężczyzna postrzega ludzi:

Człowiek to zwierzę z impulsem akumulowania dóbr, robienia zapasów. Agresywne, terytorialne, głupie. Zabijające z łatwością, gdy ktoś ma naruszyć jego interes oraz integralność. Nic więcej, nic mniej. Atawizmy. W dziewięćdziesięciu procentach składamy się z atawizmów, reszta - język, kultura, religia, etyka to tylko wypadki przy pracy [s. 100].

W Ślepnąc od świateł, podobnie jak w dziewiętnastowiecznej powieści naturalistycznej, istotną rolę odgrywa determinizm biologiczny i środowiskowy ${ }^{20}$, a w szczególności przynależność do określonej grupy zawodowej. $\mathrm{W}$ momencie, gdy pozycja społeczna zostaje zagrożona, w człowieku uaktywniają się atawistyczne odruchy, przejawiające się $\mathrm{w}$ bezdusznej walce $\mathrm{z}$ oponentami.

Interesujący wydaje się również fakt, iż bohaterowie powieści Żulczyka nie rozmawiają o Bogu, nie poruszają kwestii związanych $\mathrm{z}$ transcendencją. Żyjąc w społeczeństwie narcystycznym, nie odczuwają "głodu transcendencji" związanego ze zbawieniem jednostki, marzą wyłącznie o dobrobycie, zdrowiu, dobrostanie oraz miłości. Ciągle rosnący apetyt na powyższe wartości potęguje wyłącznie wewnętrzną pustkę i atrofię uczuć.

Jacek przypomina ponowoczesnego dekadenta, dla którego egzystencja w świecie zdominowanym przez konsumpcję pozbawiona jest głębszego sensu. Jako nihilista odrzuca wszelkie aksjomaty, zaś obserwując życie mieszkańców stolicy konstatuje: „Wszystko jest tandetne. Absolutnie wszystko jest tandetne. Wszystko w ostateczności przestaje działać i istnieć. Wszystko jest szmelcem" [s. 231].

Bohater, jako niedoszły student ASP, analizuje również symptomy kryzysu współczesnej kultury, przez co nieświadome wyraża pragnienie transgresji, „wyjścia poza granice istniejących form kultury i życia społecznego" ${ }^{21}$ :

Polska to kraina billboardów reklamujących dachówki, śmieci na poboczach, kraj cebuli i rzepaku, to królestwo skarpet, wąsów, amfetaminy. W Europie Środkowo-Wschodniej narkotyki są złe i biedne. I tanie. Nawet te drogie są tanie, tandetne i złe [s. 241].

20 Por. J. Kulczycka-Saloni, Naturalizm, w: Stownik literatury polskiej XIX wieku, red. J. Bachórz, A. Kowalczykowa, Wrocław 2002, s. 598-602; D. Knysz-Rudzka, Europejskie powinowactwa naturalistów polskich. Studia, Warszawa 1992; J. Zajkowska, Na obrzeżach nowoczesności. O powieściopisarstwie Artura Gruszeckiego, Warszawa 2015, s. 66-67.

21 Por. E. Paczoska, Od utopii artystycznej do allotopii, w: tejże, Prawdziwy koniec XIX wieku. Śladami nowoczesności, Warszawa 2010, s. 138. 
Kraj został zalany tandetnymi produktami o marnej jakości, nadrzędną wartością stało się odwieczne pragnienie zysku. Bohater dokonuje demistyfikacji jałowej kultury instant, a w owej krytyce nieświadomie uaktywnia się „marzenie o przywróceniu kulturze spontaniczności, żywiołowości, siły kreacyjnej" 22 .

Kreacja Jacka jako wyrachowanego dilera to tylko rola społeczna, w którą wcielił się protagonista. Nocą nękają go liczne koszmary mające charakter profetyczny. Niespokojny rytm onirycznych obrazów odzwierciedlają pytania natury egzystencjalnej, których mężczyzna nie zadaje w życiu codziennym. Bohater nie wie, kim jest, nie potrafi określić przestrzeni, w której się porusza. Upiorna wizja blokowiska zaciera granice między światem realnym a postapokaliptycznym. W koszmarach często obecna jest rodzina, która $\mathrm{w}$ napięciu oczekuje na nieokreślone, traumatyczne wydarzenie. W snach mężczyzny pojawia się także wizja alternatywnego życia, w którym ma żonę oraz dzieci. Warto podkreślić, iż w marzeniach sennych następuje nieoczekiwana zmiana imaginacyjnych dekoracji. Spokojny świat (locus amoenus) ulega nagłej transformacji w przestrzeń horroru (locus horridus). W trakcie podróży samochodem „świat staje się jeszcze bardziej zamazany, samochody przed nami zlewają się $\mathrm{w}$ jedną masę, jakby były $\mathrm{z}$ powoli podgrzewającej, zlewającej się w jedno modeliny" [s. 389]. W koszmarach sennych na powierzchnię wydobywa się to, co Jacek starannie tłumił i ukrywał - troska o najbliższą rodzinę.

Bohaterowie Ślepnąc od świateł, nieustannie nękani niepokojem i depresją poszukują spokoju, który zapewnia im diler narkotykowy, wcielający się niekiedy w rolę terapeuty Marian Fajkowski, celebryta i gospodarz popularnego show, który w przestrzeni publicznej kreuje się na ",szemranego nastolatka" [s. 111], mimo że już dawno skończył czterdzieści lat, podczas spotkania $\mathrm{z}$ Jackiem $\mathrm{w}$ swoim luksusowym apartamencie, pozwala sobie na takie wyznanie:

Kokaina i alkohol kochają cię najbardziej na świecie. Bezwarunkowo. Jak matka, jak Jezus Chrystus. Popatrz na to w ten sposób. Są zawsze, gdy ich potrzebujesz. Nie pytają cię nigdy o zdanie. Nic od ciebie nie chcą. Kosztują zawsze tyle samo. No dobra, wiem, akcyzy, wahania rynku, ale generalnie - kosztują zawsze tyle samo. Zawsze dadzą ci komfort. Pocieszenie. Sprawią, że poczujesz się lepiej. O każdej porze dnia i nocy. Jak to nazwać inaczej, jeśli nie miłością? Przecież to definicja miłości. Najczystszej z możliwych. O którym z ludzi w swoim życiu mógłbyś to powiedzieć? Że kochają cię tak mocno i tak czysto? [s. 125-126]

22 Tamże. 
Źródłem duchowej agonii oraz pustki we współczesnym świecie jest nic innego, jak właśnie samotność. Mariusz odczuwa permanentne zmęczenie ludźmi, nudzą go rozmowy z aktorami, politykami oraz innymi sezonowymi gwiazdami estrady. Mężczyzna ceni wyłącznie „ludzi, którzy nie mają żadnej potrzeby rozmawiać z nim" [s. 124].

Do podobnych wniosków dochodzi również drugi zamożny klient Jacka, którym jest samotna żona biznesmana. Mimo zgromadzonego majątku czterdziestopięciolatka nie czuje się szczęśliwa. Co więcej, straciła złudzenia dotyczące własnego szczęścia. W rozmowie z Jackiem stwierdza:

Jesteś jak mój mąż i jego koledzy - zapala papierosa. Jesteś taki sam jak oni, gdy mieli po trzydzieści lat. Mówili: jeszcze będzie czas, by pożyć. Na razie trzeba zarabiać. Trzeba ulepić ten pierwszy milion przed czterdziestką. Pierwsze dziesięć, dwadzieścia milionów. Ile razy ja to słyszałam? Darli mordę, jakby chodziło o klub piłkarski, który wygrał puchar, nie wiem, puchar narodów: „JESZCZE BĘDZIE CZAS!". A wiesz, gdzie oni są? Wiesz, gdzie są teraz? Może żyją, w pewnym sensie wydaje im się, że żyją, może wydaje im się nawet, że właśnie odpoczywają. W apartamentach. $Z$ kurwami. Na jachtach. Ale po prostu dalej się trzęsą, dalej srają, dalej ćpają pieniądze, ćpają ich zapach. Nie mają czasu, bo go nie ma, i ty też go nie masz, mój drogi [s. 216].

Gromadzenie majątku okazuje się zabiegiem złudnym, gdyż tylko pozornie zapewnia karierowiczom poczucie ciągłości egzystencji. Nieświadomi mijającego czasu zapominają o najbliższych, odczuwając presję związaną z utratą zarobionych milionów. Stają się zakładnikami współczesnego demiruga, jakim są pieniądze. Zrozpaczona klientka przestrzega przed konsekwencjami stylu życia współczesnych biznesmenów:

Nie ma nic poza drugą osobą. Nie ma nic, zapamiętaj. Nie ma nic poza kimś, kto jest dla ciebie bezinteresownie serdeczny. Za dziesięć lat będziesz błagał. Będziesz skamlał, słońce. Będziesz prosił obcych ludzi na ulicy, aby poszli z tobą na herbatę. Wpadli do ciebie pograć $w$ kanastę. Pojechali z tobą na wakacje. [...] Sam sobie zabrałeś swój czas i nigdy nie będziesz go miał. Jeździsz tym swoim samochodem, by zdobyć coś, czego nie będziesz umiał obsłużyć [s. 217-218].

Przekleństwem współczesnego świata okazuje się rozpad więzi społecznych, czego konsekwencją jest permanentna samotność. Bohaterka uświadamia Jackowi, iż stał się niewolnikiem własnej pracy, co w niedalekiej przyszłości wpłynie negatywnie na budowanie bliskich relacji z ludźmi. Symbolem współczesnego społeczeństwa staje się Narcyz. Wzmożony kult konsumpcji to antidotum wobec lęków znamiennych dla późnej nowoczesności, takich jak: strach przed starością i śmiercią, obawa przed rywalizacją, pogarszające się relacje międzyludzkie, samotność. 
Bohaterowie Żulczyka są jednocześnie beneficjentami, jak i ofiarami obietnic nowoczesności dotyczących realizacji mitu amerykańskiego marzenia o szybkiej karierze oraz dobrobycie. Utratę złudzeń potęguje dodatkowo zanik duchowości, której rolą, podobnie jak religii, ,,jest organizowanie znaczeń, tworzenie narracji, ocalanie kategorii i różnych sposobów myślenia" ${ }^{23}$. W Ślepnąc od świateł bohaterowie nie rozmyślają nad sensem życia, wypierają z umysłu problem starości oraz śmierci. Brak owej refleksji świadczy o głębokiej niedojrzałości. Unikają rozwiązywania wielu problemów, z którymi borykają się w życiu codziennym, wybierając alternatywne życie w narkotycznej otchłani. Duchowość zaś kojarzy się wyłącznie z troską o własne ciało, jego błogostan ${ }^{24}$. Dlatego też ciało w dobie ponowoczesnej to miejsce, w którym przedmiot i podmiot zrasta się $\mathrm{w}$ całość niepodzielną, tworząc enigmat body and soul ${ }^{25}$. Narastający głód transcendencji potęguje także uczucie "ciężkości” ${ }^{26}$, od którego pragną się uwolnić za wszelką cenę. Współczesnymi „Świątyniami konsumeryzmu" ${ }^{27}$ stają się nie tylko centra handlowe, ale również modne lokale, restauracje, w których bohaterowie Ślepnąc od świateł zapominają o nieznośnym ciężarze bytu.

Jednym z symptomów postępującego rozpadu więzi oraz atrofii społecznej jest niewątpliwie niedojrzałość. Bohaterowie Żulczyka okazują się niedojrzali, gdyż nie podejmują próby szukania pomysłów na życie, które pomogłyby im $\mathrm{w}$ opanowaniu wewnętrznego chaosu ${ }^{28}$. Wybierają złudne i chwilowe narkotykowe katharsis. Bliskie jest im wyłącznie przeżycie entropii świata oraz lęk przed utratą kontroli nad własnym życiem. Narastające antagonizmy w społeczeństwie, kryzys autorytetów wpływają na doświadczenie niespójności własnej osoby. Ową dezintegrację potęguje przestrzeń miasta-polipa, pustoszącego moralnie, wyniszczającego fizycznie i psychicznie jego mieszkańców. Życie w społeczeństwie konsumpcyjnym pozbawionym autorefleksji zatruwa umysły chorobą próżności, pogoni za modą oraz życiem ponad stan. To pieniądze deprawują ludzi, przypominając ponowoczesnego

\footnotetext{
23 J. Gray, O zgiełku wielu religii, przeł. M. Zdanowska, "Znak” 2011, nr 7/8, s. 79.

24 Z. Bauman, Duch i ciało na rynku - duchowość na sprzedaż, „Znak” 2011, nr 7/8, s. 21.

25 Tamże, s. 17.

26 "Ciężkość", jak definiuje Zygmunt Bauman, to potężny ładunek niechęci, zrozumiałej i spodziewanej jako w pełni usprawiedliwionej, która „konfrontuje nas z czymś, co nam wadzi i przeszkadza, tarasując drogę do rzeczy czy stanów, których pragniemy: od ciężaru chcemy się uwolnić, łakniemy zrzucenia go z pleców czy sumienia" [tamże, s. 18].

27 Termin ten wprowadził George Ritzer. Cyt. za: Z. Bauman, Duch i ciało na rynku - duchowość na sprzedaż, s. 22.

28 Por. E. Paczoska, Dojrzewanie, dojrzałość, niedojrzałość. Od Bolesława Prusa do Olgi Tokarczuk, Warszawa 2004, s. 48.
} 
demiurga, kuszącego oraz przyciągającego młodych spragnionych nowych rozrywek, życia w blasku splendoru tworzącego złudną iluzję szczęścia. Życie chwilą jest niezwykle trudne w świecie konsumpcyjnym, który oferuje liczne rozrywki oraz atrakcje, będące lustrzanym odbiciem banalności codziennej egzystencji. Żulczyk, rejestrując zmiany zachodzące w mentalności społeczeństwa, dochodzi do pesymistycznych wniosków: cierpimy na chroniczny głód tożsamości, co świadczy o naszej niedojrzałości społecznej.

\section{Bibliografia}

Bachórz Józef (1993), Miasto z perspektywy Kraszewskiego, w: Miasto - Kultura - Literatura. Wiek XIX, red. J. Data, Gdańsk: Wydawnictwo Gdańskie, s. 64-78.

Bauman Zygmunt (2011), Duch i ciało na rynku -duchowość na sprzedaż, „Znak”, nr 7/8, s. $17-22$.

Dąbrowski Mieczysław (2006), Literatura jako nośnik etycznego dyskursu epoki. Fin de siècle $i$ fin de millénaire, w: Etyka i literatura. Pisarze polscy lat 1863-1918 w poszukiwaniu wzorców życia i sztuki, red. E. Ihnatowicz, E. Paczoska, Warszawa: Wydawnictwa UW, s. 392-402.

Gray John (2011), O zgiełku wielu religii, przeł. Marzena Zdanowska, „Znak”, nr 7/8, s. 79-80.

Gutowski Wojciech (1993), Symbolika urbanistyczna w literaturze Młodej Polski, w: Miasto -Kultura - Literatura. Wiek XIX, red. J. Data, Gdańsk: Wydawnictwo Gdańskie, s. $189-211$.

Ihnatowicz Ewa (1993), Miasto kryminalne?, w: Miasto - Kultura - Literatura. Wiek XIX, red. J. Data, Gdańsk: Wydawnictwo Gdańskie, s. 113-124.

Knysz-Rudzka Danuta (1992), Europejskie powinowactwa naturalistów polskich. Studia, Warszawa: Wydawnictwo UW.

Kulczycka-Saloni Janina (2002), Naturalizm, w: Stownik literatury polskiej XIX wieku, red. J. Bachórz, A. Kowalczykowa, Wrocław: Ossolineum, s. 598-602.

Lasch Christopher (1991), The Culture of Narcissism. American Life in an Age of Diminishing Expectations, London-New York: W.W. Norton and Company.

Paczoska Ewa (2004), Dojrzewanie, dojrzałość, niedojrzałość. Od Bolesława Prusa do Olgi Tokarczuk, Warszawa: Wydawnictwo Sic.

Paczoska Ewa (2008), Lalka, czyli rozpad świata, Warszawa: Wydawnictwa Akademickie i Profesjonalne.

Paczoska Ewa (2010), Od utopii artystycznej do allotopii, w: E. Paczoska, Prawdziwy koniec XIX wieku. Śladami nowoczesności, Warszawa: PIW, s. 137-149.

Piechota Dariusz (2016), Śladami ponowoczesnego filistra, „Świat Tekstów. Rocznik Słupski", nr 14, s. 53-70.

Trześniewska Agnieszka (2013), Człowiek w sieci „kultury instant”. O powieści Davida Kaina "Za pięć rewolta”, „LiteRacje”, nr 2, s. 59-63. 
Zajkowska Joanna (2015), Na obrzeżach nowoczesności. O powieściopisarstwie Artura Gruszeckiego, Warszawa: Wydawnictwo Uniwersytetu Kardynała Stefana Wyszyńskiego.

Żulczyk Jakub (2014), Ślepnąc od świateł, Warszawa: Świat Książki.

\title{
Narcotic Odyssey with Social Decay in the Background: Ślepnąc od świateł by Jakub Żulczyk
}

\begin{abstract}
The article interprets Ślepnąc od światet [Blind from the Lights] as a postmodern environmental novel which shows the life of residents in a large metropolis, entangled in constant consumption. The author reads the story as a continuation of the nineteenth century novel about a social decay. He proves that the depicted society, delighted with consumer culture, is wasting its opportunities for development. As a result of the breakdown of social ties and constant work, urbanites suffer from permanent loneliness. The disillusionment is alsointensified by the disappearance of spirituality. The crisis of authority and social antagonisms further undermine the integrity and the sense of coherence in the self. But Żulczyk's characters fail to reflect on life, which the author of the article sees as the sign of immaturity.
\end{abstract}

Keywords: novel, narcissistic society, drugs, consumerism, space 